\title{
A Few Ways of Memorizing Intermediate Japanese Grammar for Students Majoring in Japanese Language
}

\author{
Huynh Tan Hoi \\ Language Department, FPT University, Vietnam
}

\begin{abstract}
Grammar is one of the important parts in the pursuit of Japanese language by all Japanese language students in particular and those who have a passion for Japanese in general. Grammar is always necessary when creating a complete sentence to be able to communicate and communicate with the opponent. However, especially at the intermediate level of Japanese, many students will find it confusing and difficult to understand and remember for a long time. Therefore, this article is completed based on survey results from 26 students of FPT University in Ho Chi Minh City. The article uses analytical and qualitative methods to find appropriate and effective methods of memorizing intermediate Japanese grammar in the learning process. Through the survey results, it shows that FPT University students have many methods of memorization through various forms such as books and newspapers, application to daily communication and practice. These methods are all effective for improving the Japanese grammar learning process of Japanese language students at FPT University.
\end{abstract}

Keywords: FPT University, Japanese, Intermediate grammar, Memory, Students.

\section{INTRODUCTION}

In today's increasingly advanced information revolution 4.0, language is an indispensable part of education and training to develop the country. Besides, Japanese is gradually being developed widely in society and is interested by many people. However, Japanese is said to be a difficult language that requires learners to learn a lot of skills to be able to conquer the complex pictographic alphabet system, the standard pronunciation, and especially the grammatical structure in contrast to Vietnamese (Sato, 2019). For all students of Japanese language, grammar is always a big part that makes it difficult to absorb lessons and also because of its complex nature, many meanings and usage must be in the right context. Along with Japanese culture, the way to memorize grammar also becomes more difficult, hindering the learning process. Next, to be able to communicate fluently and apply it well in work, learners need to have a good grasp of intermediate grammar structures. This is quite difficult level to be able to memorize all the sentence patterns in detail and apply it every day. If the study is not done properly, it can be boring and cannot be applied when students participate in the learning process. Memorizing all the grammar effectively requires perseverance and approaches to memorization methods, from which learning and practicing Japanese becomes simpler and easier.

\section{Literature Review}

Japanese is now widely used in many countries, including Vietnam, so the demand for learning Japanese is increasing. It is because Japanese is the only language used in its own country and the concept of "national language" ( $(\mathbb{})$ has also proven its monolingual characteristics and properties that are always different from all languages that have caused many problems and difficulties for learners ( $\mathrm{Vu}, 2019)$. However, in order to be effective in the learning process, finding and proposing methods of memorizing grammar is still essential for all Japanese language students. According to Nam (2010), how easy or difficult it is to succeed in teaching explicit grammar depends a lot on what stage of development the learners are at. For example, learners are at intermediate level, it is easier to teach obvious grammar. It will be difficult to succeed when learners are still at the beginning stage just like learning and memorizing grammar depending on the ability of each student will have their own appropriate method. In this study, three methods have been proposed to innovate learning methods so that students can choose and implement because if they only focus on common grammar theory, it will lead to results that are not applicable, practical and ineffective to students (Nam, 2010). Therefore, changing the way of learning with these methods will be effective for students.

\section{The Status of Memorizing Grammar of FPT STUDENTS}

The type of Japanese is an agglutinative language in contrast to Vietnamese, which is an isolated language, so there are

Corresponding Author e-mail: hoiht@fe.edu.vn

https://orcid.org/0000-0002-9323-3123

How to cite this article: Hoi HT (2022). A Few Ways of Memorizing Intermediate Japanese Grammar for Students Majoring in Japanese Language. Pegem Journal of Education and Instruction, Vol. 12, No. 1, 2022, 25-30

Source of support: Nil

Conflict of interest: None.

DOI: $10.47750 /$ pegegog.12.01.03

Received: 25.09 .2021

Accepted: 12.11.2021 Publication: 01.01.2022 
many differences in grammatical structure and always make it difficult for students to approach and master. Grammatical structure is always the main part to create sentences and use in communication and reading comprehension. More specifically, in Japanese grammar, when learning, there are many types of particles with different meanings. Moreover, the same Japanese grammar structure can be used in many contexts, expressing a variety of nuances of the speaker, including certain rules and many different meanings. In addition, unlike many languages, Japan always focuses on the formal form, so in terms of grammar, there is also a system of honorifics and humility to express respect to elders and superiors, modesty towards themselves. Therefore, if students do not know the grammar well, they will easily confuse and use it ineffectively.

According to a survey of 26 Japanese language students conducted at FPT University in Ho Chi Minh City, it shows that the number of students who correctly and effectively use intermediate grammar in usual communication and normal writing are quite small. In addition, students often use simple elementary structures, easy to understand, so they do not attract listeners and readers. Many students think that because acquiring knowledge, applying skills (Chi, 2017) does not apply much to reality, the structure is not common in life and is complicated, so memorizing grammar is always difficult in the process of participating in the program. In addition, it is because the learner plays an active role, detecting problems, gathering information, analyzing information, building a problem-solving roadmap, and learning actively (Hue, 2020), subjective factors are equally important, but the number of students who have not rationally used their self-study time along with ineffective learning methods also accounts for a part. However, there are objective factors such as the limited learning environment that makes it difficult for students to concentrate, lack of reference materials to analyze and deeply understand the grammar structure, and not enough time to practice for the students who are financially independent. Through the above problems, it can be seen that students' practice of memorizing Japanese grammar is having many difficulties. To overcome these situations, students must change and rationally use their study time to be more effective (Fotos, 2005).

\section{Memorization Methods}

Mind mapping is a method that has been introduced as a powerful means of taking advantage of the brain's ability to record images. This method was developed in the late $60 \mathrm{~s}$ (20th century) by Tony Buzan (psychologist), in the process of memorizing key words to remember combined with arrows and illustrations according to the rules, students' own creation, from which to build a picture to easily visualize the problem to remember.
The method is performed through the following steps. First, you will have to identify keywords and structure patterns to remember. Next, draw the main topic at the center of the diagram, from which it develops into specific ideas, draw more sub-branches if need further analysis. Finally, decorate with illustrations to make it easier to visualize and remember. The more vivid the diagram, the more attractive it will be for longterm memory (Candidates, 2021).

In addition to traditional grammar learning methods such as memorization, the practical application method will also bring high efficiency. In this method, learners will apply all the knowledge they need to remember through real-life communication, good writings or we can call it as practical practice. Moreover, when used in many cases when applied in practice, learners can gain a lot of experience for the process of learning to write, the structure patterns are difficult when used often and corrected in case of mistake. Opponent words will have a great impact on memorizing grammar with high efficiency (Benati, 2018).

Through the theory of memory and learning ability called the gap effect, Hermann Ebbinghaus (a psychologist) has developed a method of interval repetition, which is a skill to increase the time between revisions to exploit the psychological effect of interruption, helping to improve memory ability with a large amount of content over a long period of time (Aqel, 2013).

How to implement this method will take a long time, but it is very useful and highly effective for students. Memory cards together with the "Leitner system" - a system of small boxes used to store memory cards marked from 1 to 5 will be the main accessories in the process of learning this method. Students will put flashcards containing content to remember in the box, the newest content will be placed in the first box at number 1 and the old content will be placed in the next box at number 2 . Those cards will be reviewed. Practice every day until you understand, then put it on the next gear box and so on. In case students can't remember the old content, they will move that card to the first box to start again, and in the case when they reach box 5 and remember the content, they can leave it out. Through this method students can understand their memory level with that content.

The 「〜上で」 grammar has two use cases. The first is a way of saying that "must do action V first" and means "after (already) ..." with the structure



Noun $(\mathrm{N})++$ 上で

For example:

工事計画 は, 周辺住民との話し合いのうえで決 められるべきだ.

(Translation: The construction plan should be decided after discussing with the people around) The second is the way of saying that "in the process, in case of doing something, etc" which means "when-in the process" with the structure Pegem Journal of Education and Instruction, ISSN 2146-0655 
2. Verb dictionary form $(\mathrm{V} ・ \mathrm{~V}$ する $)+$

For example:

このプロジェクトを進めていく上で障害とな

るのが, 地元の住民の反対運動だ.

(Translation: The obstacle we will encounter in carrying out this project is the protest activity of the local people.)

\subsubsection{Application to the method of using mind maps}

In this method the main content will be the grammar $\lceil\sim$ 上

で」 drawn in the center of the diagram.

After the match, draw the branch into two cases of the structure 「〜上で」 further analyze the meaning of two cases. Students can branch out more examples to be more specific.

Because this structure pattern 「〜上で」 is quite common, it is easy to apply in daily communication in work and study by students. In one day, to remember this structure, students will try to use it many times in many communication environments, then practice every day by creating their own structured conversations. In addition, students can apply when writing or refer to more examples in books and newspapers. This method is both effective for memorization and can practice speaking and writing skills, which is a useful method for students in the learning process.

The structure $\lceil$ 上で」 is divided into two cases as introduced above. This method first needs to fill in the meaning of each case of the grammar form 「〜上で」 on both sides of the card.

It is clear that one side will be the grammar structure, the other side will be the meaning of that grammatical structure pattern and put a card with case 1 in box 1 in a sequence of 5 boxes. On the first day, if students can memorize it, they will put the full card in box number two to review tomorrow and put the next card with case 2 in box number one to memorize. Similarly, the next day, students will check their knowledge of card number one, if they remember, they will skip the next box and put card number 2 in box 2 and so on practice to box 5 .
Although this method is complicated and time-consuming, it brings long-term memorization effects.

\section{Methods, Subjects and Scope of Research}

This study will use analytical and qualitative methods to find methods for memorizing intermediate Japanese grammar for students in an appropriate, effective and correct way method (Yoshiko, 2019) in the learning process. First of all, the article will collect documents through Japanese and written articles and references related to the topic and then re-selected to suit the research paper. Next, "selective selection" (Uchimaru, 2012) will be developed to form the survey questions on the situation of remembering Japanese grammar for students. The survey will be conducted with 26 students majoring in Japanese at FPT University in Ho Chi Minh City. After statistics of the survey results, the article will analyze the advantages, disadvantages and effectiveness of memorization methods to find out how to increase learners' knowledge (Chi, 2017) and remember effectively. And for a long time. Within the scope of this article, this study will refer to three main methods of memorization: the method of using mind maps, the method of practical application and the method of interrupted repetition, more specifically the study of three previously mentioned methods is considered in the [[ ${ }^{\sim}$ 上で] structure. At the end of the study, we will summarize all, give problems about memorization skills and the most appropriate method for students to increase learners' knowledge (in the process of participating in learning and taking notes).

\section{Research Results}

To find out the most appropriate memorization method and the importance of grammar learning for students, a number of survey questions combined with face-to-face interviews were conducted with FPT university students.

Table 1 shows that the level of students' interest and assessment of intermediate grammar is difficult up to $77.3 \%$ of the total students, only $13.6 \%$ of students consider it very

Table 1: Level students' interest in intermediate grammar

\begin{tabular}{|c|c|c|c|c|}
\hline \multirow{2}{*}{ Questions } & \multicolumn{4}{|c|}{ Total: 26 students } \\
\hline & A & B & $\mathrm{C}$ & $\mathrm{D}$ \\
\hline \multirow{2}{*}{ How do you rate intermediate Japanese grammar? } & Very difficult & Difficult & Quite easy & Easy \\
\hline & 3 & 17 & 1 & 1 \\
\hline \multirow{2}{*}{$\begin{array}{l}\text { How often do you use intermediate Japanese grammar } \\
\text { structures? }\end{array}$} & Usually & Often & Sometimes & Never \\
\hline & 3 & 11 & 8 & 0 \\
\hline \multirow[t]{2}{*}{ When do you apply intermediate level grammar patterns? } & $\begin{array}{l}\text { When studying at } \\
\text { school }\end{array}$ & $\begin{array}{l}\text { When working at } \\
\text { company }\end{array}$ & $\begin{array}{l}\text { When } \\
\text { communicating } \\
\text { with friends, } \\
\text { teachers }\end{array}$ & $\begin{array}{l}\text { When studying } \\
\text { and working and } \\
\text { communicating }\end{array}$ \\
\hline & 13 & 1 & 1 & 7 \\
\hline
\end{tabular}


difficult. Grammar is an important factor. The level of use by students sometimes accounts for $50 \%$, only $13.6 \%$ is frequent and no student does not use it. Therefore, Japanese grammar at the intermediate level is very popular and interested by many students, so memorizing grammar is also an important factor in the learning process (Nam, 2010).

In addition, almost $59.1 \%$ of students apply intermediate grammar only when studying at school, a good grammar is often considered as a grammar that appears in writing or official speeche (Nam, 2010), moreover, in face-to-face interviews, many reasons say that because of the difficulty of grammar and poor speaking skills, use simple grammars so that the other side can understand the meaning of expression, so the application of intermediate grammar is not really popular in work communication environments.

When it comes to the memorization method in Table 2, most students choose the method of learning grammar through many means (books, comics, etc.) and spend about 30 minutes a day doing it. In addition, learning a foreign language helps to increase language knowledge, cultural interpretation capacity (Chi, 2017), but the above results also show that students do not really spend a lot of time to review and memorize grammar every day only accounts for $13.6 \%$. The methods of learning are quite diverse, including ideas about focused learning in class. For students, learning by the method will impress and help memorize grammar quickly and effectively.

In addition, in the process, students also face their own difficulties, most of which are due to the subjective factor as participating in activities close to reality, going beyond the framework of the classroom to acquire knowledge in a timely manner actively (Hue, 2020) which has not really been added to that with the problem of not spending much time reviewing grammar. The rest is due to the difficulty of the grammar structure and the objective factors are the same as in the interview. Directly interviewing students considered that the difficulties in the learning process were mainly due to the remaining review time due to difficult grammar and insufficient reference materials for better understanding and memorization (Table 2).

The method of using mind maps, although less popular, is still known by $18.2 \%$ of students. However, the method of practical application is highly appreciated by the students for its popularity. The rest is the method of interval repetition, which is a fairly new method and is used by few students but is effective, students can learn quickly and their grammar will also reach a high level (Nam, 2010) with long-term memory process (Figure 1).

With all three methods (mind map method, practical application method, intermittent repetition method) are popular and the method highly appreciated by students is practical application method. Through this method, students believe that if they can be applied regularly, they will remember the grammar for a long time, and their speaking and listening skills will also be improved (Figure 2).

These methods are difficult to use because students do not have time to implement, besides the relatively complicated process is also the main reason when students apply. Moreover, students think that the two methods of using mind maps and the method of intermittent repetition are still not very popular with no understanding of the implementation process, which makes it difficult for students to want to apply the method. This is in the process of memorizing intermediate grammar and applying it.

Besides these difficulties, these methods still bring a certain effect to students who can easily understand grammar skills without confusing contexts, which is an advantage that students appreciate the most. Memorizing more grammar is also a high effect for students in the learning process.

\section{Recommendations}

First, to memorize grammar, students need to firmly grasp the positions of the auxiliary verbs and the structure of the grammar

Table 2: Students' grammar memorization process

\begin{tabular}{|c|c|c|c|c|}
\hline \multirow[b]{2}{*}{ Questions } & \multicolumn{4}{|c|}{ Total: 26 students } \\
\hline & $A$ & $B$ & C & $D$ \\
\hline \multirow{2}{*}{$\begin{array}{l}\text { How long do you spend every day } \\
\text { studying grammar? }\end{array}$} & Around 10 minutes & Around 30 minutes & Around 60 minutes & Others \\
\hline & 3 & 17 & 1 & 1 \\
\hline \multirow[t]{2}{*}{$\begin{array}{l}\text { What learning methods do you } \\
\text { usually use to memorize grammar? }\end{array}$} & Daily practice & $\begin{array}{l}\text { Study through media } \\
\text { (newspaper, comics, etc.) }\end{array}$ & $\begin{array}{l}\text { Give examples from grammar } \\
\text { structures }\end{array}$ & Others \\
\hline & 3 & 11 & 8 & 0 \\
\hline \multirow[t]{2}{*}{$\begin{array}{l}\text { In your opinion, what problems } \\
\text { cause difficulties in the process } \\
\text { of learning and memorizing } \\
\text { intermediate level grammar? }\end{array}$} & $\begin{array}{l}\text { Typical difficulty level of } \\
\text { grammatical structures }\end{array}$ & $\begin{array}{l}\text { Due to subjective factors (not } \\
\text { properly using the study time, } \\
\text { not focusing on the lesson, } \\
\text { etc.) }\end{array}$ & $\begin{array}{l}\text { Due to objective factors } \\
\text { (limited learning } \\
\text { environment, lack of } \\
\text { references, not enough study } \\
\text { time, ...) }\end{array}$ & Others \\
\hline & 9 & 11 & 2 & 0 \\
\hline
\end{tabular}




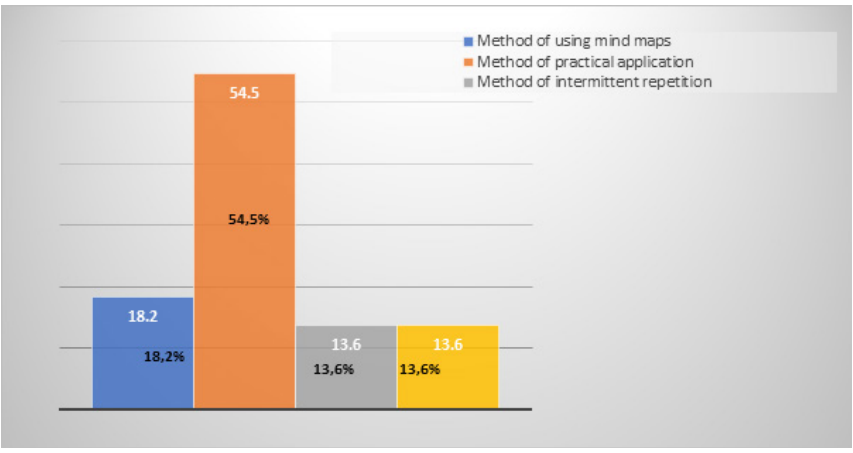

Fig.1: Popularity of intermediate grammar memorization methods

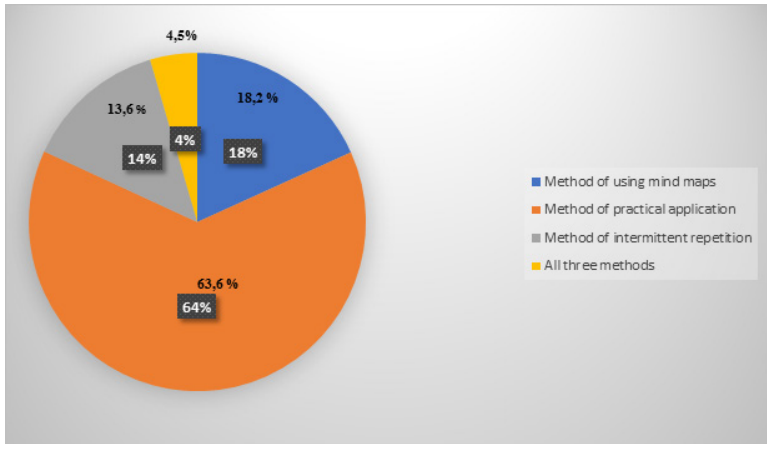

Fig. 2: Effective methods of memorizing intermediate grammar

Table 3: Difficulties and advantages of mnemonic methods

\begin{tabular}{|c|c|c|c|c|c|c|c|c|}
\hline \multirow[b]{2}{*}{ Questions } & \multicolumn{8}{|c|}{ Total: 26 students } \\
\hline & 1 & 2 & 3 & 4 & 5 & $\begin{array}{l}\text { Total of } \\
\text { answer }\end{array}$ & $\begin{array}{l}\text { Total } \\
\text { scores }\end{array}$ & $\begin{array}{l}\text { Average } \\
\text { level }\end{array}$ \\
\hline $\begin{array}{l}\text { Methods to save students' time studying } \\
\text { grammar }\end{array}$ & 0 & 5 & 10 & 7 & 0 & 26 & 68 & 0,10 \\
\hline $\begin{array}{l}\text { Opportunity to practice speaking and listening } \\
\text { skills when applying memorization method }\end{array}$ & 0 & 0 & 5 & 7 & 10 & 26 & 93 & 0,11 \\
\hline $\begin{array}{l}\text { Improve your ability to memorize a lot of } \\
\text { grammar for a long time }\end{array}$ & 0 & 5 & 5 & 7 & 5 & 26 & 78 & 0,09 \\
\hline $\begin{array}{l}\text { Memorization method helps students not } \\
\text { to confuse the context of each grammatical } \\
\text { structure when it is being used }\end{array}$ & 0 & 0 & 10 & 5 & 7 & 26 & 85 & 0,10 \\
\hline $\begin{array}{l}\text { Memorization method attracts students, does not } \\
\text { cause boredom in the learning process }\end{array}$ & 0 & 3 & 11 & 8 & 0 & 26 & 71 & 0,08 \\
\hline The method is not yet popular with students & 0 & 8 & 3 & 0 & 11 & 26 & 80 & 0,09 \\
\hline $\begin{array}{l}\text { The method should have simple preparation and } \\
\text { implementation }\end{array}$ & 0 & 0 & 3 & 8 & 11 & 26 & 96 & 0,11 \\
\hline $\begin{array}{l}\text { The method is difficult to apply and implement } \\
\text { in the process of memorization }\end{array}$ & 0 & 0 & 8 & 3 & 11 & 26 & 91 & 0,10 \\
\hline $\begin{array}{l}\text { The method does not help clarify structures } \\
\text { when memorizing }\end{array}$ & 0 & 0 & 3 & 11 & 8 & 26 & 93 & 0,11 \\
\hline \multirow[t]{2}{*}{ Method does not attract students } & 0 & 0 & 8 & 11 & 3 & 26 & 83 & 0,09 \\
\hline & & & & & & & 838 & 0,98 \\
\hline
\end{tabular}

for easy analysis and avoid causing confusion. Moreover, in order to communicate better, it is equally necessary to memorize, grasp and use intermediate grammatical structures. Once the structure is firmly grasped, understanding long and complex dialogue sentences (Yoshiko, 2019) along with applying them to the sentence structure will be easy, making the communication sentences become smooth, natural and unbroken. If students encounter such an error, memorization will also become convenient and fast.

Second, students need to recount the structural patterns they have learned and will learn in the future. This will make it easier to assess the level of memorization and learning, and to know if there is a need for further study or review of forgotten structures. If statistics and regular assessment are made, memorization will become more effective in the learning process (Loewen, 2009).

Third, through other media such as newspapers, other media is also a means of meeting learners' needs (Uchimaru, 2012) and also a way to practice and memorize grammar. Students will choose and practice reading or listening passages suitable to their ability and level through these means, from which to practice in this way, memorizing grammar will be simple and other skills will also be improved. 
esides the mnemonic equations, passion and perseverance are indispensable in the process of receiving and learning Japanese language. For complex structural models that have caused many difficulties for students, perseverance, review every day, spend more time practicing, seriously study under the guidance from the school, learn more about structural patterns through reference materials are very important to make the knowledge and thinking of learners will become richer and more flexible (Chi, 2017) to be effective when learning. Persistence is a good virtue to have when working and studying, when this trait is trained, it will help students quickly focus and create efforts to improve and memorize grammar knowledge.

In addition, passion is also the fueling energy to overcome challenges, which is an important and indispensable factor when learning any foreign language, including Japanese. Students with passion will create interesting ways of learning, always looking for unknown or unknown grammar patterns, if they study Japanese only for personal reasons without the pursuit and passion, they will find it difficult to achieve the language effectively and easily. It causes problems of discouragement and difficulties in the learning process (Lundqvist \& Sandström, 2019).

\section{ConcLusion}

Intermediate Japanese grammar is a difficult part but also a very important part to make complete sentences. Therefore, memorizing intermediate Japanese grammar structures is very necessary in the student's participation program. In the process of memorizing grammar, students need daily practice, regularly applying the grammar learned through conversations in the learning and working environment to improve their understanding. In addition, students who often memorize by conventional learning methods can easily become bored and unattractive. Therefore, in addition to the traditional ways, the mentioned memorization methods will make the learning process more interesting, although the above memorization methods are not very popular with students, but they will help save time and increase memory efficiency. Moreover, the memorization time will be longer and avoid confusion about the context of use when applying these methods.

\section{LiMITATIONS}

Because of the limited knowledge and additional information, through this study on methods of memorizing intermediate Japanese grammar, in case there are shortcomings and any problems, please ignore and hope the research will be completely improved in the future.

\section{Acknowledgement}

To be able to complete the research paper, I have received a lot of enthusiastic guidance from the lecturers and the comments and participation in the survey of FPT University students during the research process. Sincere thanks to the lecturers and students for their guidance and contributions to the completion of this study.

\section{References}

Sato, M. (2019). Exploring EFL Learners' Attitudes towards Topicbased Lexical Network and Form-based Grammatical Network Activities. The Asian EFL Journal, 53-71.

Fotos, T. S. (2005). Traditional and grammar translation methods for second language teaching. In Handbook of research in second language teaching and learning (pp. 677-694). Routledge.

Loewen, S., Li, S., Fei, F., Thompson, A., Nakatsukasa, K., Ahn, S., \& Chen, X. (2009). Second language learners' beliefs about grammar instruction and error correction. The Modern Language Journal, 93(1), 91-104.

Zdanevych V. Larysa; Popovych Oksana; Tsehelnyk M. Tetiana; Novak M. Olena; Kasianenko Oksana. "Practice and innovation inclusive education in pre-school institutions". Journal for Educators, Teachers and Trainers, 11, 1, 2020, 46-55. doi: 10.47750/jett.2020.11.01.005

Lundqvist, J., \& Sandström, M. (2019). A bioecological content analysis: an analysis technique rooted in the bioecological model for human development. International Journal of Early Childhood Special Education, 11(2), 194-206.

Candidates, T. (2021). Related Knowledge Levels of Speech Language Therapist Candidates. International Journal of Early Childhood, 13(1), 54-61.

Aqel, I. M. (2013). The effect of using grammar-translation method on acquiring English as a foreign language. International Journal of Asian Social Science, 3(12), 2469-2476.

Benati, A. (2018). Grammar-Translation Method. The TESOL Encyclopedia of English Language Teaching, 1-5.

前田直子. (2007). 中級 -上級の日本語文法教育. 研究年報/学習院 大学文学部, (53), 71-9

小林由子. (2019). 2. 課題遂行型授業における語彙・文法学習の位 置づけ: 中級理解 (基礎) 3A の実践加. 日本語・国際教育 研究紀要, 22, 28-45.

野呂智哉, 橋本泰一, 徳永健伸, \& 田中穂積. (2005). 大規模日本語 文法の開発. 自然言語処理, 12(1), 3-32.

Uchimaru, Y. (2012). 中級日本語学習者が望む学習とは何か-高等教 育機関におけるアンケート調査. 大学教育研究紀要, 8, 61-72.

小野正樹. (2005). 日本語教師の「上級文法」のとらえ方一中国 語母語話者教師と日本語母語話者教師へのアンケート調査 から一. 日本語教育方法研究会誌, 12(2), 4-5. 